\title{
Chapter 19 \\ One Size Does Not Fit All: Private-Sector Perspectives on Climate Change, Agriculture and Adaptation
}

\author{
Kealy Sloan, Elizabeth Teague, Tiffany Talsma, Stephanie Daniels, \\ Christian Bunn, Laurence Jassogne, and Mark Lundy
}

\subsection{Introduction}

Agricultural researchers understand that there are no one-size-fits-all solutions to production issues: variations in climate, soil, farmer experience and many other factors mean that any advice must be specifically tailored to the given context (OsorioCortes and Lundy 2018). It is less well understood, however, that private sector supply-chain actors exhibit just as much variability, and also require tailor-made solutions. Civil society and public-sector donors, when working with businesses often lump them under a generic heading and approach them in the same way. To effectively engage private-sector to make substantial contributions to the promotion of climate-smart agriculture (CSA), they must be understood and approached in more nuanced ways.

This paper assesses how private-sector actors from different parts of the supply chain view, understand, and engage with climate change and the promotion of CSA practices. The private sector is increasingly at the center of market systems approaches because of their ability to facilitate innovation, access to producers and continuity of initiative (Vorley et al. 2009, Lundy et al. 2003). Our analysis draws

\author{
K. Sloan · S. Daniels \\ Sustainable Food Lab, Hartland, VT, USA \\ e-mail: ksloan@sustainablefood.org; sdaniels@ sustainablefood.org \\ E. Teague \\ Root Capital, Cambridge, MA, USA \\ e-mail: eteague@ rootcapital.org \\ T. Talsma $\cdot$ C. Bunn $\cdot$ M. Lundy $(\bowtie)$ \\ International Center for Tropical Agriculture (CIAT), Cali, Colombia \\ e-mail: t.talsma@cgiar.org; bunn@cgiar.org; t.talsma@cgiar.org; m.lundy@cgiar.org \\ L. Jassogne \\ International Institute of Tropical Agriculture (IITA), Oyo, Nigeria \\ e-mail: L.Jassogne@cgiar.org
}


on semi-structured interviews and broader engagement with 42 private firms working in coffee, cocoa and other commodity crops ("Private Sector Consultation" 2018). ${ }^{1}$ Our findings indicate that many food and beverage companies already support action on climate change, at least in general terms. Most, however, say that they need more guidance on climate risks and CSA solutions, in order to deepen and scale their engagement. This study indicates that efforts to encourage private supplychain actors to embrace CSA should emphasise the following efforts: (i) offering granular, subnational-level climate-risk data that will allow companies to integrate CSA into their broader risk-management strategies; (ii) providing CSA information and resources that are tailored to companies' specific position within the supplychain; and (iii) emphasising the business case for CSA to make CSA uptake viable for companies that are held accountable to revenue goals.

\subsection{Provide Granular Data to Assist in Risk Management}

Most food and beverage companies recognise that climate change both exacerbates business risks and threatens ongoing sustainability efforts. In spite of this, many are reluctant to act because of uncertainty about how and when their supply chains will be affected, what role they should play and how to coordinate a response that is a part of holistic sourcing and sustainability strategies. Even those companies that are already taking action require more information in order to engage more deeply and at scale.

All companies conduct risk management as a core commercial function, and our interviews showed most food and beverage companies now routinely include climate change as one aspect of risk assessment. Companies generally spoke of two categories of climate-change risk: operations risk, or risk to physical assets such as processing facilities; and supply-chain risk, or risk of supply disruption. Risk varies according to the companies' physical footprint and supply-chain concentration. For instance, the mainstream cocoa and chocolate industry is heavily exposed to supplychain risk, because most of the world's cocoa comes from West Africa, a region already experiencing the effects of climate change. The industry recognises the immediate and long-term threat of climate change to both the livelihoods of farmers and to a stable supply, as well as the pressures on forest health that may result from these threats (Lundy 2017).

\footnotetext{
${ }^{1}$ The Learning Community for Supply Chain Resilience, funded by USAID's Feed the Future program, interviewed 18 coffee companies (roasters and traders), 11 cocoa and chocolate companies (brands and traders) and 13 grain and ingredient companies. The goal was to better understand how they think about climate-smart agriculture, the types of activities in which they engage, and the types of climate information they use and/or need. Coffee and cocoa companies feature prominently because of the vulnerability of their supply chains to climate change: Coffee and cocoa are tree crops with long productive life cycles, and most producers are smallholder farmers in lowincome countries.
} 
Despite widespread recognition of climate-change risks, most companies are at the early stages of developing strategies that explicitly address CSA. Interviews revealed most companies address select pillars of CSA but rarely all three in a cohesive manner. For example, corporate sourcing and sustainability programs usually seek to increase productivity (the first pillar of CSA) via training, inputs, credit and efforts to strengthen community-level institutions. Multinational companies often have policies focused on reducing greenhouse gas emissions (the second pillar) in facilities under their direct control. Yet companies rarely reported efforts related to adaptation (the third pillar), in large part because adaptation action requires climate data that is more detailed than what is commonly available (Private Sector Consultation 2018).

\section{What does climate action in the supply chain look like?}

Some food and beverage companies are already moving from risk assessment to action. The trader Olam, for example, committed to buy climate-smart cocoa, which secured market access for farmers, and to pay premiums for Rainforest Alliance-certified cocoa. Similarly, coffee companies like Coop Coffee, JDE, Keurig Green Mountain, Lavazza and Nestlé are promoting CSA across their supply chains through training programs such as the Initiative for Coffee \& Climate from the NGO Hanns R. Neumann Stiftung, or finance initiatives like the Coffee Farmer Resilience Initiative and the Rust Relief Fund.

Most companies interviewed explained that, as they make their first steps toward deepening their engagement in CSA, they would like the research community to clarify the key differences between CSA practices and long-promoted "good agricultural practices". All companies interviewed positioned their interest in CSA as an extension of both ongoing risk-management practice and sustainability programs focused on socio-economic development, environmental conservation and supply security through good agricultural practices. The companies seek to make their existing efforts more climate-smart rather than implementing new, isolated programs (Private Sector Consultation 2018).

The companies also expressed interest in particular types of data that would help inform their climate strategy. With some exceptions, most companies sought (i) granular (i.e., generally subnational) climate-risk data to diagnose and monitor their supply-chain and operational risks; (ii) guidance on specific, practical technologies to build resilience; (iii) more robust quantification of the economic impacts of climate change across producing regions; and (iv) risk projections for companion and/ or alternative crops in regions facing diversification or transition. The companies called for this information to be more accessible: They would like researchers to provide more user-friendly data, such as brief fact sheets available through a central portal rather than academic papers housed behind a paywall (Private Sector Consultation 2018). 


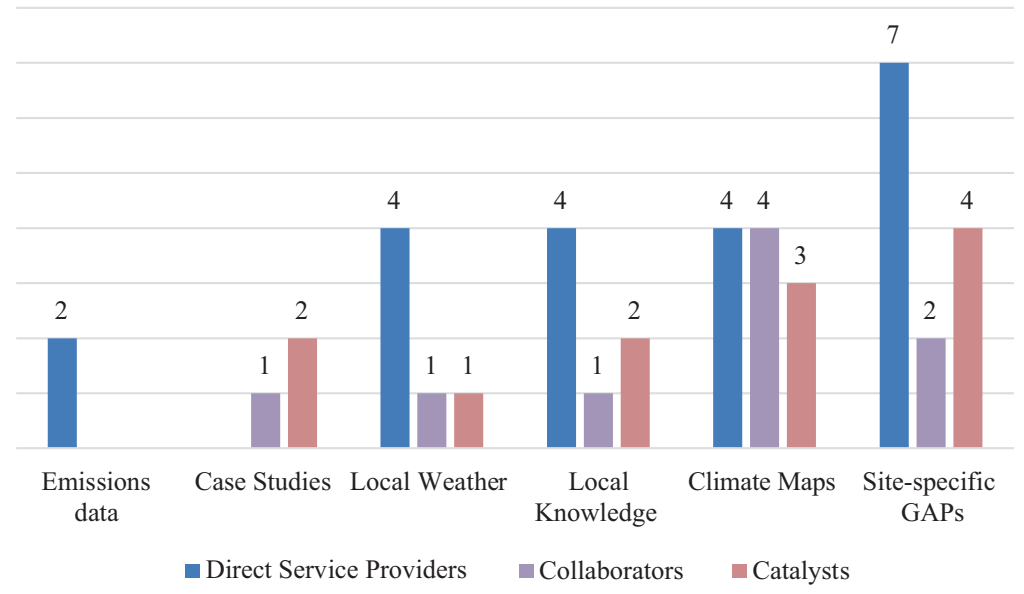

Fig. 19.1 Demand for climate change information by role (multiple choices allowed)

\subsection{Tailor Information to Companies' Position in Supply Chain}

Because food and beverage companies adopt different CSA strategies based largely on their position within the supply chain, researchers and policymakers should seek to tailor information and resources to suit individual needs.

Based on our research, we divided actors in the supply chain into three different

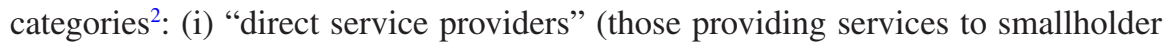
farmers) such as ECOM Agroindustrial Corp. Ltd., (ii) "collaborators" (those working with direct service providers to deliver services to smallholder farmers), such as JDE, and (iii) "catalysts" (those working at a high level on climate issues with a light touch at the farm level), such as Tchibo. These actors get their climate information through a variety of different sources (Fig. 19.1).

Depending on their role, these actors see climate change through different lenses (see Table 19.1). Direct service providers were unlikely to distinguish between climate and sustainability efforts, but rather focused on holistic programs to increase productivity and make farming viable for today's farmers and attractive for the next generation. These companies were driven to action by farmer needs and were most interested in local knowledge and site-specific practices to help farmers adapt to climate change. Collaborators were more dependent on the direct service providers for information to shape their program design and often worked in partnership at a slightly higher level, looking to area-specific climate maps and case studies on successful programming to inform a broader strategy. Catalysts were more likely to be involved in broader, often industry-level conversations and interventions about

\footnotetext{
${ }^{2}$ Each category is followed by an example of a coffee company that fits that particular "role" in the typology.
} 
Table 19.1 Access to and demand for climate information, by role within supply chain

\begin{tabular}{|c|c|}
\hline Role & Access to and demand for climate information \\
\hline \multirow{2}{*}{$\begin{array}{l}\text { Direct service } \\
\text { providers }\end{array}$} & Currently have the most access to detailed farm-level data \\
\hline & $\begin{array}{l}\text { Seek more local information to supplement existing knowledge, such as } \\
\text { changing local weather patterns and site-specific good agricultural practices } \\
\text { (GAPs) that pair with their specific climate risks }\end{array}$ \\
\hline \multirow[t]{2}{*}{ Collaborators } & $\begin{array}{l}\text { Are dependent on the direct service providers for information to shape their } \\
\text { program design and implementation }\end{array}$ \\
\hline & $\begin{array}{l}\text { Often work in collaborations at a slightly higher level, looking to area- } \\
\text { specific climate maps and case studies on successful programming to inform } \\
\text { a broader strategy }\end{array}$ \\
\hline \multirow[t]{3}{*}{ Catalysts } & $\begin{array}{l}\text { Rely on secondary sources of information from sector groups, such as sector } \\
\text { platforms and trade groups, as well as desk research to answer particular } \\
\text { questions }\end{array}$ \\
\hline & Seek broad origin and risk mitigation information to inform global strategy \\
\hline & $\begin{array}{l}\text { May provide funding for research or services provision, may be visible as } \\
\text { leaders in the sector, and may be interested in risk at origin, but rarely } \\
\text { implement programs on the ground }\end{array}$ \\
\hline
\end{tabular}

climate change without directly intervening at the farm level. These companies seek multi-site risk mitigation and origin information to inform global strategy and collaborative solutions, often through sector platforms (Private Sector Consultation 2018).

Given the different needs of the actors with varying roles in the supply chain, researchers and policy makers should focus on providing the information most relevant to each. The varied demand for different types of information between different company roles can be seen in Fig. 19.1

\subsection{Make the Business Case for CSA}

Companies first and foremost are for-profit entities. They may see the need for longer-term solutions, but have to remain competitive and ensure they are meeting short-term financial goals as well as securing future supply. Whenever possible, researchers should emphasise return on investment and cost of inaction while connecting long-term climate projections to short-term productivity gains that both benefit the companies and build greater resilience in the agricultural system (Private Sector Consultation 2018).

For private companies, investment in CSA is driven primarily by efforts to secure a reliable supply and to avoid risks to their reputations. Supply security depends largely on the quantity sourced (those sourcing smaller quantities are less likely to feel this impact directly) and the sourcing region (the impacts of climate change are experienced more severely in some areas than in others). In the case of companies sourcing products of especially high quality, impacts can be pronounced even when volumes are low, if the regions that produce those goods are hard-hit by climate 
change. Reputational risks can range from severe to inconsequential, depending on the expectation by the consumer and/or the added value of a product grown according to climate-smart standards.

The degree to which companies choose to- or find themselves able to-invest in CSA depends on a range of factors. Among companies interviewed, those with dedicated sustainability staff embedded within procurement and sourcing departments often reported having an easier time incorporating CSA into their core sourcing strategies. Companies known for sustainability principles are often better able to prioritise such investment than their peers. In contrast, companies with shareholders who demand shorter-term profitability or quality results often have a more difficult time justifying the need for longer-term investment (Private Sector Consultation 2018). This is in line with recent findings on the determinants of corporate commitments to reduce deforestation as well (Lambin et al. 2017).

For most companies, private investment is a viable choice when contained within the company's own supply chain. As a lead firm, they are able to directly provide incentives to support CSA adoption amongst producers up the chain. However, when the benefits are less tangible or at risk for "leakage", blended finance models are well suited to these types of investment that deliver both public and private goods. This entails deliberate use of funds from capital providers with a range of financial and impact return expectation, from philanthropic capital with a negative rate of return, to those seeking capital preservation and below-market to market-rate returns (Private Sector Consultation 2018). Blended finance approaches can attract capital for investments addressing market failures or delivering significant social or environmental impact in emerging and frontier markets and enable more thoughtful longer-term investments in resilience by private sector actors.

Although many of the food and beverage companies surveyed already invest in CSA to some degree, they stressed the need for tangible, short-term business cases to justify ongoing investments in CSA. Companies must be able to capture the benefits of such investments via gains in volume or quality, increased supplier loyalty or deferred costs (Private Sector Consultation 2018).

\subsection{Implications for Development}

Our research highlights the need for the scientific community to provide more detailed, actionable information to incentivise companies' investments in CSA. Understanding the role each company plays in the supply chain - as direct service providers, collaborators or catalysts - can help define the type of information needed. Insights and approaches that effectively connect long-term climate projections with short-term productivity and weather variability are still needed to increase alignment between existing productivity focused approaches and effective CSA investments (Fig. 19.2) 
6

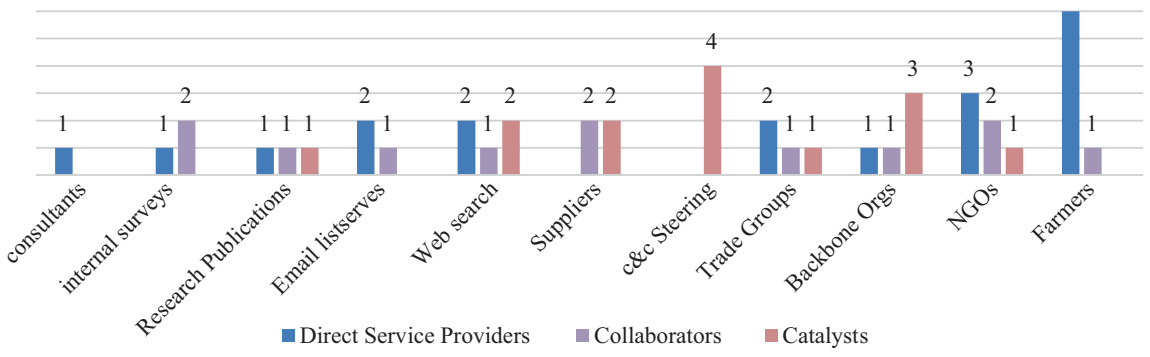

Fig. 19.2 Sources of climate-change information for various actors within the coffee industry (multiple choices allowed)

\section{References}

Lambin F, Gibbs HK, Heilmayr R et al (2017) The role of supply-chain initiatives in reducing deforestation. Nat Clim Chang 8:109-116. Available from:. https://doi.org/10.1038/ s41558-017-0061-1

Lundy, M. (2017) Private Sector Development in Middle Income Countries. International Fund for Agricultural Development

Lundy M, Gottret MV, Cifuentes W, Ostertag CF, Best R (2003) Diseño de estrategias para aumentar la competitividad de cadenas productivas con productores de pequeña escala. International Center for Tropical Agriculture, CIAT, Rural Agroenterprise Development Project, Cali

Osorio-cortes, L. E., \& Lundy, M. (2018). Scaling-Up Behaviour Change in Market Systems Development: A literature review. CGIAR Research Program on Policies, Institutions, and Markets (PIM), International Food Policy Research Institute (IFPRI).

Private Sector Consultation on Climate Smart Agriculture (2018) [online] Available at: http:// sustainablefoodlab.org/wp-content/uploads/2018/01/Private-Sector-Consultation-on-ClimateSmart-Agriculture-FtF.pdf [Accessed 29 Mar. 2018].

Vorley, B., Lundy, M., and MacGregor, J. (2009) Business models that are inclusive of small farmers. Agroindustries for Development, Wallingford, UK: CABI for FAO and UNIDO, 186-222

Open Access This chapter is licensed under the terms of the Creative Commons Attribution 4.0 International License (http://creativecommons.org/licenses/by/4.0/), which permits use, sharing, adaptation, distribution and reproduction in any medium or format, as long as you give appropriate credit to the original author(s) and the source, provide a link to the Creative Commons license and indicate if changes were made.

The images or other third party material in this chapter are included in the chapter's Creative Commons license, unless indicated otherwise in a credit line to the material. If material is not included in the chapter's Creative Commons license and your intended use is not permitted by statutory regulation or exceeds the permitted use, you will need to obtain permission directly from the copyright holder.

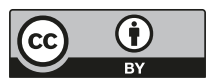

